\title{
$\beta$-Galactosidase marker genes to tag and track human hematopoietic cells
}

\author{
Claude Bagnis, Christian Chabannon, and Patrice Mannoni \\ Centre de Thérapie Génique, Institut Paoli-Calmettes, Centre Régional de Lutte contre le Cancer, \\ Marseille, France.
}

Key words: LacZ; human hematopoiesis; stem cell; gene marking; retroviruses; gene therapy.

A nalysis of the behavior and fate of hematopoietic cells in vivo is an effective method of improving our understanding of normal hematopoiesis, which relies on a complex interactive network including cytokines, chemokines, physical contact, and undefined interaction kinetics, and of establishing the use of hematopoietic cells as therapeutic vehicles in gene therapy. ${ }^{1}$

Analysis of animal models or patients reinfused with hematopoietic cells is considered important in addressing these issues. In an autologous context, the most relevant context for this purpose, the tracking of reimplanted cells is impossible to achieve without markers that are able to discriminate between reinfused cells and host cells; this emphasizes the need to develop safe, efficient, and easily performed marking strategies. The injection of nontoxic chemical markers has been widely used to study the embryonic development of animal models; however, fluorescein-conjugated dodecapeptides, rhodamine-conjugated dextran, or horseradish peroxidase molecules are diluted during successive divisions of marked cells, thus making long-term studies difficult. $^{2-5}$ Differences in heterochromatin density in the quail/chicken chimera model have provided informative results but cannot be applied to other animal models. ${ }^{6}$ Defective retroviruses have been found to be very interesting cell markers in a number of situations, including preclinical and clinical models, because retroviruses are natural vectors that are able to stably integrate into the genome of the transduced cell; this allows detection of the provirus in the progeny of genetically modified cells, but in situ detection of a few transduced cells remains difficult. ${ }^{7,8}$

A good experimental cell marker must exhibit the following properties: the expression of the marker must be (a) absent from the cells to be tagged, (b) genetically

Received January 3, 1998; accepted May 14, 1998.

Address correspondence and reprint requests to Dr. Claude Bagnis, Centre de Thérapie Génique, Institut Paoli-Calmettes, Centre Régional de Lutte contre le Cancer, 232 Boulevard Sainte-Marguerite, 13273 Marseille cdx 9, France. E-mail address: bagnisc@marseille.fnclcc.fr

(c) 1999 Stockton Press 0929-1903/99/\$12.00/+0 transmissible, and (c) easily detectable in situ; in addition, the marker gene or its expression product should not be horizontally transmissible. To achieve these goals with the aim of tagging human hematopoietic cells, we decided to use the retroviral transfer of the bacterial $\beta$-galactosidase ( $\beta$-gal) activity encoded by the LacZ gene as a cell-marking activity.

\section{THE LacZ GENE}

\section{LacZ and neomycin-resistance (neoR) genes}

Thus far, only the neoR gene that induces resistance to G418, a neomycin analog, has been used as a genetic marker in clinical trials dealing with hematopoietic cells. Several studies have been completed that have provided interesting information on hematopoietic recovery after stem cell transplantation, or on the origin of relapse in patients undergoing autologous transplantation. More than 20 gene-marking clinical trials using neoR have been performed or are under investigation and have demonstrated gene transfer and resistance to G418 in a very small percentage of the reinfused cells. ${ }^{9-12}$ However, the use of neoR is hampered by several problems. Polymerase chain reaction analysis provides statistical data regarding only integration of the proviral sequence in the studied cell population. This assay does not necessarily demonstrate transgene expression, nor does it give information about individual transduced cells. An analysis of gene expression with the antibiotic resistance assay is limited to clonogenic cells that exhibit different sensitivities to G418 depending upon their nature (i.e., burst-forming units-E, granulocyte-macrophage colonyforming units (CFU), etc.). ${ }^{13}$ Finally, some reports suggest that the neophosphotransferase encoded by the $n e o R$ gene induces modifications of cellular metabolism or may act as a transcriptional silencer in eukaryotic cells. ${ }^{14-16}$ Therefore, the search for transgenes encoding an activity that is both innocuous and easily recognizable in situ has led to the use of marker genes such as the LacZ gene. 


\section{The LacZ gene}

General information. The bacterial LacZ gene which was isolated from the $\mathbf{z}$ cistron of the Escherichia coli lactose operon encodes $\beta$-gal, a glycoside hydrolase. The 3081-base pair coding sequence encodes a nonglycosylated protein of 1027 amino acids with a molecular mass of $\sim 11 \mathrm{kDa}^{17}$ The active enzyme is a tetramer that is made up of four identical monomers encoded by the $L a c Z$ sequence.

Optimal $\mathrm{pH}$ and endogenous activity. Mammalian cells possess endogenous $\beta$-gal involved in lactose metabolism and glycolipid and mucosubstance catabolism. These enzymes are found mainly in lysosomes. Bacterial $\beta$-gal works optimally at a neutral $\mathrm{pH}$, whereas mammalian $\beta$-gal requires an acidic $\mathrm{pH}(\mathrm{pH} 4-5) .{ }^{18}$ Thus, by selecting appropriate reaction buffers, it is possible to preferentially observe the enzymatic activity attributable to the exogenous bacterial $\beta$-gal. ${ }^{19}$ In addition, chloroquine treatment of the cells can increase the internal $\mathrm{pH}$ of lysosomes and consequently prevent detection of the endogenous $\beta$-gal activity. ${ }^{20,21}$

Subcellular localization. In mammalian cells, the LacZ gene product is found mainly in the cytoplasm. ${ }^{22}$ When chromogenic substrates are used for in situ detection, cells expressing $L a c Z$ can be visualized by their cytoplasmic staining surrounding a pale lighter area (the unstained nucleus). In CV-1 cells, it has been shown that $\beta$-gal has no membrane component and cannot be found exposed at the cell surface. ${ }^{23}$ Moreover, $\beta$-gal is not able to cross intracellular or synaptic junctions; consequently, marking activity does not leak from $L a c Z$-expressing cells to neighbor cells that do not express the LacZ gene. $^{24}$

Alternatively, the development of a fusion protein composed of the nuclear localization sequence of the simian virus $40 \mathrm{~T}$ antigen $(\mathrm{Ag})$ at the $5^{\prime}$ end of the $\mathrm{LacZ}$ coding sequence results in a $\beta$-gal enzyme that is located primarily in the nucleus of eukaryotic cells. ${ }^{22,25}$ Expression of the fusion protein nls- $L a c Z$ during mitosis suggests that the location of the enzyme is mostly perinuclear. Using photon microscopy, $\beta$-gal staining is not diffuse throughout the nucleus, but rather appears as a dark rim on the external face of the nuclear membrane. Galileo et al reported that the nuclear localization of nls- $\beta$-gal is not totally stable, with a cytoplasmic staining in $1 \%$ of postmitotic nls- $\beta$-gal ${ }^{+}$embryonic cells in vitro. ${ }^{26}$

Detection of expression of the LacZ gene. Expression of the $L a c Z$ gene or its derivatives can be detected using various substrates. ${ }^{27}$ Cellular extracts can be analyzed using $O$-nitrophenol- $\beta$-D-galactoside or 4-methyl-umbelliferyl- $\beta$-D-galactoside, but these assays do not provide information for individual and identifiable cells. Only two substrates are used for the detection of single cells expressing a $\beta$-gal activity within a population of nonexpressing cells. Staining with 5-bromo-4-chloro-3-indolyl$\beta$-D-galactoside (X-Gal), which involves the degradation of X-Gal into galactose and a blue-indigo chromogene product, is the most widely used assay for the detection of transduced cells. ${ }^{28}$ It is worth noting that cells have to be fixed before addition of the substrate. X-Gal degradation can be inhibited by $4-\beta$-D-galacto-D-glucose. ${ }^{7} \mathrm{~A}$ recent report suggests that the use of this detection strategy in vivo may underestimate the extent of gene expression compared with the immunostaining performed with monoclonal or polyclonal antibodies. ${ }^{29}$ The use of fluorescein digalactose (FDG) combined with fluorescence-activated cell-sorting (FACS) analysis offers an interesting alternative. FDG is a galactose complex that traps and inactivates a fluorescein molecule which can be released as an active form by $\beta$-gal activity. The FDG-FACS assay is the most sensitive $\beta$-gal detection assay, because 1-10 enzyme molecules per cell are enough to detect a $\beta$-gal activity; in contrast, 100-1000 molecules per cell are necessary to achieve a positive X-Gal staining. In addition, the staining of cells with FDG does not require the fixation of cells and allows the sorting and subsequent culture of viable cells. ${ }^{27,30-33}$ However, because FDG is a large molecule, the staining procedure requires a gentle permeation of cell membranes using a mild osmotic shock, which makes this practical approach rather difficult when assaying primary hematopoietic cells. Lipophilic alternatives to FDG have been developed, but the interest of these molecules still remains to be demonstrated. ${ }^{33}$

LacZ and cell behavior. Most of the results published thus far concern nonhematopoietic cell or tissue types; several examples are reported below. Sanes et $\mathrm{al}^{7}$ have shown that the growth of murine NIH-3T3 fibroblasts infected with a retrovirus coding for the $L a c Z$ gene is identical with that of noninfected NIH-3T3 cells. Furthermore, the same experiments have also shown that the percentage of LacZ-expressing cells remains stable over 50 cell divisions. The $L a c Z$ gene was also used as a reporter gene to analyze the transcription of specific or ubiquitous promoters in different cell and tissue types. $L a c Z$ was transferred to the cotton rat or to nonhuman primate airway epithelium using adenoviral vectors in preparation for a clinical trial of cystic fibrosis. ${ }^{34-36}$ The gene encoding $\beta$-gal was also transferred to neuronal $^{37-40}$ and retinal cells, ${ }^{41-43}$ keratinocytes, ${ }^{44,45}$ bladder ${ }^{46}$ and gallbladder cells, ${ }^{47}$ mesangial and tubular cells, ${ }^{48,49}$ endothelial and other vascular cells, ${ }^{50-54}$ skeletal and heart muscle cells, ${ }^{55-59}$ hepatocytes, ${ }^{60-63}$ salivary gland cells, ${ }^{64}$ and even thyroid follicular cells ${ }^{65}$ using different, mostly adenoviral vectors in different species. In these experiments, limited side effects were observed and were believed to be related to the vector itself, ${ }^{34,51,57,65,66}$ rather than to the $L a c Z$ gene or its product. Moreover, in animal models, transgenic mice for $L a c Z$ did not exhibit toxicity, ${ }^{67}$ and transfer of the $L a c Z$ gene into fertilized eggs ${ }^{68}$ did not affect the embryonic and larval development of the African catfish.

To our knowledge, no report exists stating that $\beta$-gal can be toxic to human hematopoietic cells, which strongly express the $L a c Z$ gene. It has been assumed that the product of the nls- LacZ gene may be toxic in certain 
conditions. ${ }^{69,70}$ However, our results demonstrate that expression of the nls-LacZ gene is not deleterious to human primary hematopoietic cells such as $\mathrm{CD} 34^{+}$ progenitors and their progeny. ${ }^{71}$

$\beta$-gal and immunogenicity. An immune reaction against cells expressing a foreign $\mathrm{Ag}$ has already been shown for nonself proteins expressed in transduced cells reinfused into patients. ${ }^{72,73}$ As shown in animal models,${ }^{74}$ bacterial $\beta$-gal by itself exhibits immunogenic features, but it is worth noting that the long-term expression of a transduced $L a c Z$ gene into immunocompetent animals has already been reported in several instances. ${ }^{75,76}$ Whether or not the intrinsic immunogenic properties of a retrovirally transduced bacterial $\beta$-gal are sufficient to elicit an immune reaction which is able to eradicate transduced hematopoietic cells in humans remains unknown. ${ }^{66}$ It should be expected that the combination of several parameters, including the vector strategy used, the reinfusion route, the level of expression, and the genotype of the recipient, will be involved in triggering off such an immune-mediated rejection of cells expressing $\beta$-gal.

Conclusion. Altogether, these results suggest that the use of native or modified $L a c Z$ genes does not affect cell behavior, and that $\beta$-gal can be envisaged as a safe marker for both in vitro and in vivo experiments.

In parallel to the $\beta$-gal activity encoded by the $L a c Z$ gene, alternative easily detectable markers should also be carefully considered; these markers include alkaline phosphatase and alcohol dehydrogenase ${ }^{77}$ or proteins that can be directly detected by fluorescence, such as the green fluorescent protein from jellyfish and its derivatives. ${ }^{78-82}$

\section{CHOICE OF VECTORS AND PRODUCING CELL LINES}

The efficiency and safety of nonviral transduction procedures, such as lipofection or wave-shock transfection, have to be clearly established before they can be used to genetically modify hematopoietic cells for clinical trials. Currently, transduction procedures using viral vectors seem to provide the most efficient approach. ${ }^{83}$ Because early hematopoietic progenitors will actively proliferate to give rise to their differentiated and multilineage progeny, integration of the transgene in the genome is an absolute prerequisite to obtain long-term expression of the transgene. Therefore, the use of nonintegrating vectors such as adenoviruses is inappropriate in this situation and is restricted to therapies in which only short-term expression of the transgene is required. ${ }^{84}$ Conversely, retroviral vectors and adeno-associated viral vectors can integrate the genome, and the transgene remains present in the progeny of the infected cells.

\section{Retroviral vectors}

Retroviruses are natural vectors that can be engineered to transfer genes. ${ }^{83}$ For safety considerations and insert- size limitations, trans-active viral sequences are excised and replaced with exogenous sequences to be transferred. Because these modified retroviruses are replication-defective, the production of viral particles is performed using transcomplementing packaging cell lines. During viral infection, viruses bind to target cells through specific receptors. ${ }^{85,86}$ After entry of the virus, reverse transcriptase transcribes viral RNA into doublestranded DNA that randomly integrates into the genome of the eukaryotic target cell. The new genetic information remains stable in the host cell and will be transmitted to its progeny during mitosis. ${ }^{8}$

Because the $L a c Z$ is only 3 kilobases long, ${ }^{17}$ it can be transferred using any available retroviral vector alone or

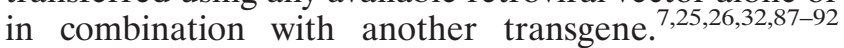
Most retroviral vectors derive from the Moloney murine leukemia virus; only a few of these defective vectors, such as GN1a and LNL 63 or MFG derivatives,${ }^{94}$ have been used for gene-marking clinical trials. Vectors derived from murine retroviral backbones different from Moloney murine leukemia virus ${ }^{95}$ are being tested for their potential to lead to a better expression of the $\mathrm{Lac} Z$ gene or its $n l s-L a c Z$ derivative in hematopoietic cells. The main limitation associated with the use of murine retroviral vectors is that integration in the genome requires cell division ${ }^{96}$ and quiescent cells, such as very early hematopoietic progenitors, are difficult to infect. Promising strategies based on use of lentiviral-derived vectors able to transduce quiescent cells are now under development. ${ }^{97}$

The choice of the packaging cell line to transduce human hematopoietic cells remains difficult, because no clear comparative data have been reported regarding the relative ability of Psi-Crip, ${ }^{94} \mathrm{GP}+$ envAm $12,{ }^{98} \mathrm{PA} 317,{ }^{93}$ PG13, ${ }^{99} 293$ cell-derived BING, ${ }^{100}$ or HT-1080-derived ${ }^{101}$ producing cell lines to transduce hematopoietic cells. Data obtained from different laboratories led to the hypothesis that the efficiency of transduction is not strictly related to viral titer and can differ from one producing clone to another. ${ }^{71,102-107}$ This hypothesis strongly argues for screening of the producing cell on the basis of its ability to infect the hematopoietic cell to be transduced rather than on the basis of titration assays performed on accessory cells such as murine fibroblasts. ${ }^{107}$ In addition, prospects for in vivo gene therapy led to the conclusion that new packaging cell lines have to be designed that are able to produce viral particles not sensitive to the inhibitors present in human sera or able to produce targeted viral particles. ${ }^{101,108}$ In fact, all retroviral vector packaging cell lines currently developed can be used to produce LacZ-containing retroviral vectors.

\section{Adeno-associated viruses (AAV)}

Efficient gene transfer into $\mathrm{CD} 34^{+}$cells using AAV has been reported. ${ }^{109,110}$ The mechanisms of integration, efficiency of gene transfer (including efficient packaging cell lines), integration, and expression in dividing and nondividing hematopoietic cells remain to be clearly 
defined for AAV. ${ }^{111,112}$ It will be especially interesting to learn whether the relative site-specific integration of AAV into the AAVS1 site on chromosome 19q13.3-qter will provide any advantage for gene transfer and gene therapy purposes. ${ }^{109}$ The safety of viral supernatants (absence of replication-competent viruses) must also be improved for clinical purposes. Transfer of the $L a c Z$ gene with AAV-derived vectors into hematopoietic cells has already been reported, but long-term expression of this gene in transduced hematopoietic cells remains undocumented. ${ }^{69,70,110}$

\section{Combination of viral vectors}

Very interesting investigations involve the combined use of nonintegrative vectors, such as adenoviral vectors, for the in situ delivery of retroviral vector sequences and transcomplementing genes, thus taking advantage of two different gene transfer strategies. Such strategies provide interesting approaches in transducing hematopoietic cells in vivo or in transducing target cells from transient packaging accessory cells in vitro, such as stromal cells. ${ }^{113}$

\section{EX VIVO RETROVIRAL TRANSFER AND EXPRESSION OF LACZ ACTIVITY IN HUMAN HEMATOPOIETIC CELLS}

\section{LacZ activity in hematopoietic progenitors}

As observed in vivo in humans and animal models, it is now established that the cell populations that participate in hematological reconstitution express the CD34 surface $\mathrm{Ag}$ and combine the expression of Thy-1 (CD90) or the absence of CD38 associated with the lack of expression of lineage-differentiated markers $\left(\mathrm{Lin}^{-}\right)$. Thus, the $\mathrm{CD}^{+} 4^{+}$cell population originating from either bone marrow, mobilized peripheral blood, or cord blood is the most relevant cell compartment to target with the purpose of long-term maintenance of therapeutic information during the lifespan of a patient. ${ }^{114}$

Transfer of the $L a c Z$ gene into mononucleated bone marrow cells and the subsequent expression of cytoplasmic $\beta$-gal were first reported by Strair et al. ${ }^{32}$ The expression of $\beta$-gal was sufficient to allow cell sorting and the enrichment of $\mathrm{X}-\mathrm{Gal}^{+}$clonogenic cells. In our experience, expression of the $L a c Z$ gene in primary $\mathrm{CD} 34^{+}$cells has been difficult to detect with X-Gal staining, whereas detection of $n l s-L a c Z$ was easier and more reproducible. ${ }^{71}$ In addition, discrimination between endogenous and exogenous $\beta$-gal activity is easier using $n l s-L a c Z$-mediated nuclear localization of the staining; the high nucleoplasmic ratio of immature cells favors the use of nuclear membrane staining.

As a model, we used TF-1, which is a growth factordependent cell line derived from an erythroleukemic patient. ${ }^{115}$ This cell line still expresses CD34 as well as CD33 and a variety of other Ags. Its growth is strictly dependent upon exogenous growth factors, including interleukin-3 (IL-3), granulocyte-macrophage colonystimulating factor (GM-CSF), or erythropoietin. By cocultivating TF-1 cells with an MFG- $n l s-L a c Z$ vectorproducing cell line, $\leq 80 \%$ of the TF- 1 cells were transduced. The percentage of cells expressing the nuclear form of $\beta$-gal in the TF- 1 cell population remained stable over a 2 -month period. Subsequently, the percentage of $n l s-L a c Z$-expressing cells slowly decreased, reaching $1 \%$ after 12 months of culture, because of an inhibition of the long terminal repeat-mediated transcription of the transgene. Presence of the provirus is detectable in the unstained cell population using a polymerase chain reaction assay. Treatment with a demethylating agent such as $5^{\prime}$-azacytidine increases the percentage of X-Gal ${ }^{+}$cells. This observation and oth$\mathrm{ers}^{28}$ suggest that DNA methylation may partly explain the decrease in $\beta$-gal expression in transduced cells. No morphological (Wright-Giemsa staining) or proliferative (growth curve kinetics, tritiated thymidine analysis, and the percentage of cells in different phases of the cell cycle) differences were observed between $n l s$-LacZ-expressing and nonexpressing cells. The expression of differentiation markers, growth inhibition by transforming growth factor- $\beta$ and interferon- $\alpha$, and differentiation in response to IL-4 and erythropoietin were also unchanged in the transduced cell population. ${ }^{71}$

Using mobilized peripheral blood $\mathrm{CD} 34^{+}$cells at 2 days after the transduction step and cocultivating target cells and producers for 3 days or cultivating $\mathrm{CD} 34^{+}$cell populations with viral particles containing cell culture supernatants, $10-50 \%$ of the cells were determined to be transduced as assessed by X-Gal staining. Methylcellulose assays demonstrated the presence of transduced clonogenic cells with $\mathrm{X}-\mathrm{Gal}^{+}$blast-forming units-E, granulocyte $\mathrm{CFU}$, macrophage $\mathrm{CFU}$, and granulocyteerythrocyte-megakaryocyte-monocyte-CFU. The same results were reported using cord blood $\mathrm{CD} 34^{+}$cells as targets. ${ }^{116}$ Expression of the nls-LacZ gene was also observed in colonies derived from more immature cells, such as high proliferative potential colony-forming cell colonies derived from transduced fetal liver $\mathrm{CD} 34^{+} \mathrm{CD} 38^{-} \mathrm{Lin}^{-117}$ or transduced peripheral blood $\mathrm{CD} 34^{+}$Thy $^{+}$cell populations. ${ }^{118}$

As indicated previously, transfer of the $L a c Z$ gene into immunoselected $\mathrm{CD} 34^{+}$human progenitor cells using AAV-derived vectors has already been achieved. ${ }^{69,70}$ Up to $70 \%$ of the transduced $\mathrm{CD} 34^{+}$cell population was found to express the transgene as assessed by X-Gal staining; however, detection of chromogenic activity of the bacterial $\beta$-gal in differentiated colonies was not reported. Transduction of human erythroleukemia cells using the same vector has also been reported, but with lesser efficiency $(\leq 3 \%) .{ }^{69} \mathrm{It}$ should be noted that transfer of the LacZ gene using adenoviral vectors ${ }^{84}$ or human cytomegaloviral vectors $^{119}$ has already been tested.

\section{LacZ activity in differentiated cells}

T lymphocytes. Among lymphoid cells, $\mathrm{T}$ lymphocytes are interesting targets for gene therapy. ${ }^{120} \mathrm{~T}$ cells are affected in several genetic diseases or infected with HIV 
in AIDS. In addition, they are (or could be) effector cells in cancer, recognizing tumor cells and contributing to their elimination through cellular- and humoral-mediated killing. Conversely, $\mathrm{T}$ cells are only alternative targets for gene therapy of genetic diseases, because they are not able to self-renew when reinfused into the patient, thus requiring a repeat patient treatment every 5-6 months. The in vitro generation of $\mathrm{T}$ cells from precursors using liquid or organotypic cultures still remains a technical challenge; ${ }^{121}$ however, in contrast with stem cells, $\mathrm{T}$ cells are neither rare nor difficult to identify and can be derived from hematopoietic or nonhematopoietic tissues.

Marking T cells with $L a c Z$ would provide information on survival, homing, the long-term proliferation of autologous, genetically modified $\mathrm{T}$ cells, and the long-term expression of transduced activity. Various coding sequences including neoR, ${ }^{122}$ herpes simplex virus thymidine kinase, ${ }^{123,124}$ human $\mathrm{CD} 4,{ }^{125}$ and a truncated version of the human low-affinity nerve growth factor receptor, ${ }^{73,124}$ were retrovirally transduced into $\mathrm{T}$ cells derived from peripheral blood ${ }^{124,126}$ or resected tumors. ${ }^{127}$ The culture and transduction of cells require stimulation, which can be performed with a combination of IL-2 and phytohemagglutinin ${ }^{123-125,128,129}$ or with a combination of antibodies directed against CD3, CD2, or CD28. ${ }^{126}$ Retroviral transduction of the $\beta$-gal activity encoded by various genetic forms of the $L a c Z$ gene, including the regular $L a c Z$, the $n l s-L a c Z$ gene, and the Sh-ble::LacZ fusion gene has been successfully tested in prestimulated human $\mathrm{T}$ lymphocytes derived from peripheral blood cultivated in the presence or absence of feeder cells. ${ }^{126,129-131}$ When using a cocultivation procedure to transduce cells and a selected producing cell line that exhibits a good ability to transduce human hematopoietic cells, we found that $\leq 80 \%$ of $\mathrm{T}$ cells were transduced, as assessed with X-Gal staining, without any deleterious effect on cell behavior. ${ }^{126}$ Unfortunately, this good transduction efficiency was only obtained with a selected producing cell line. In our hands, the transduction of T lymphocytes usually ranges from 5 to $30 \%$ of $\mathrm{X}-\mathrm{Gal}^{+}$cells as reported by several laboratories. An analysis of $\mathrm{CD}^{+}$and $\mathrm{CD} 8^{+}$cells indicated that the two populations were equally transduced and expressed the LacZ gene. ${ }^{126,132}$ The proliferation and expression of various cell surface markers, including CD3, CD25, HLA-DR, CD49b (very late Ag-4), CD4, and CD8 were found unchanged after the transduction and expression of the marker. ${ }^{126}$ It has also been shown that the LacZ product does not inhibit the T-cell differentiation of progenitor cells in fetal thymic organ cultures. ${ }^{133}$

Dendritic cells (DCs). DCs are professional Ag-presenting cells that are involved in the activation of T lymphocytes during an immune reaction. DCs are considered as key targets to be manipulated to trigger an immune reaction against tumor cells. Transducing DCs with retroviral vectors has been approached both at the level of mature cells derived from the peripheral blood ${ }^{134}$ and at the level of immature dendritic progenitors ${ }^{135,136}$ present in the $\mathrm{CD} 34^{+}$fraction. In fact, an expression of bacterial $\beta$-gal activity was either reported in retrovirally transduced DCs originating from a peripheral blood mononuclear cell culture with GM-CSF and IL- $4^{134}$ or detected in $\mathrm{CD} 1 \mathrm{a}^{+} \mathrm{CD} 14^{-}$cells derived from transduced $\mathrm{CD} 34^{+}$-mobilized peripheral blood cells cultured in the presence of GM-CSF and tumor necrosis factor- $\alpha$ (Celia Chishportich, C. B., and P. M., unpublished data).

Macrophages. It is possible to obtain macrophages either from a long-term culture of $\mathrm{CD} 34^{+}$cells or directly from peripheral blood or other nonhematopoietic tissues. The expression of $L a c Z$ activity into macrophage cells has been successfully assessed by X-Gal staining of macrophages generated from retrovirally transduced bone marrow, mobilized peripheral blood, or cord blood $\mathrm{CD}_{3} 4^{+}$cells. $^{71}$ As of yet, no report has depicted the retroviral transfer of the $L a c Z$ gene or its derivative into fully differentiated human macrophages; however, the possibility of expressing this marker gene into cultured primary monocytes has already been shown using transfection procedures. ${ }^{137}$ It is worth noting that macrophages usually exhibit a high level of endogenous $\beta$-gal activity, which makes the use of a nuclear localized version of this enzyme in the marking of these cells more interesting.

Natural killer (NK) cells. The expression of the nls-LacZ gene into NK cells by the generation of $\mathrm{X}-\mathrm{Gal}^{+} \mathrm{NK}$ cells from retrovirally transduced cord blood $\mathrm{CD} 34^{+}$cells cultivated in presence of IL-15 is under investigation. Experiments performed in fetal thymic organ cultures showed that NK cell differentiation of $\mathrm{CD} 34^{+}$progenitors was not modified by the expression of a retrovirally transduced $L a c Z$ gene. ${ }^{133}$

\section{FROM PRECLINICAL ANIMAL MODELS TO PATIENTS}

\section{Preclinical models}

Most animal experiments were designed using the neoR gene rather than the $L a c Z$ gene to tag and track hematopoietic cells. For example, the use of retroviruses to transfer the neoR gene into hematopoietic progenitors has been widely used to study the contribution of different cell populations in hematopoietic recovery in mice, ${ }^{138-143}$ dogs, ${ }^{144-146}$ or nonhuman primates. ${ }^{103,147,148}$ Interesting data were reported by Champseix et $\mathrm{al}^{149}$ using the expression of a cell surface marker coding sequence in a retrovirally transduced cord blood immature hematopoietic cell population reimplanted into immunoincompetent nonobese diabetic severe combined immunodeficient mice.

Retroviral transfer of the $L a c Z$ gene into avian leukemic cell lines or avian preosteoclastic cells, reinfusion of the cells into living embryos, and tracking of the cells in the hatched chicken using X-Gal staining have been reported. ${ }^{150,151}$

In the murine model, Savatier et $\mathrm{al}^{67}$ showed expression of a retrovirally transduced $L a c Z$ gene in the red 
blood cells of transgenic mice. An infusion of retrovirally transduced $\mathrm{CD} 34^{+} \mathrm{CD} 38^{-} \mathrm{Lin}^{-}$cells derived from the fetal liver into immunoincompetent severe combined immunodeficient-Hu mice led to a sustained expression of the $n l s-L a c Z$ gene in primitive and committed clonogenic progenitors, mature myeloids, and $\mathrm{B}$ and $\mathrm{T}$ lineage cells for $\leq 4$ months after injection. ${ }^{117}$

\section{Clinical trials}

Currently, neoR is the only coding sequence that has been used as a marker gene in clinical trials aimed at genetically tagging hematopoietic stem cells. Genemarking clinical trials have focused on the contribution of infected progenitors to hematopoietic recovery in cancer patients receiving high-dose chemotherapy conditioning regimens ${ }^{9-11}$ or on the role of the residual tumor cells present in the graft in the occurrence of relapse in a variety of malignancies. ${ }^{152}$ Previously, neoR was used by several groups to track tumor-infiltrating lymphocytes; ${ }^{127}$ data have been published ${ }^{73}$ that take advantage of a mutated form of the nerve growth factor receptor to detect transduced $\mathrm{T}$ lymphocytes in cancer patients.

\section{CONCLUSION AND PERSPECTIVES}

Using $L a c Z$ as a marker is an effective approach to (a) assess the efficacy of new transduction protocols or vectors and (b) tag and track hematopoietic cells in vivo in animal models or in clinical trials.

New procedures to genetically modify hematopoietic cells could be tested with the $\beta$-gal activity encoded by the $L a c Z$ gene. Ex vivo manipulation of hematopoietic cells still needs to be improved. The frequency of transgene integration could be assessed using X-Gal staining or FDG-FACS when testing new cytokine associations, ${ }^{153,154}$ the coculture of target cells and stromal cell lines, ${ }^{146,155,156}$ the use of extracellular matrix protein $^{157,158}$ and antagonists or agonists of cycle protein regulators. In parallel, the improvement of a gene transfer tool to benefit both ex vivo gene therapy and future prospects for in vivo gene therapy can be approached using a marking strategy. Control of transgene expression must be improved, both in terms of sustained expression of a heterologous coding sequence and in terms of time and tissue specificity. Specificity of expression has already been envisaged using either specific promoters ${ }^{159-161}$ that can direct expression of the transgene in specific cells or inducible promoters, such as those containing a Tat activating region element, whose expression is induced by the HIV Tat protein. ${ }^{162,163}$ Long-term expression of the transgene has to be addressed through the analysis of factors involved in the decrease of transgene expression, ${ }^{164-166}$ such as the hypermethylation of DNA, ${ }^{167,168}$ or interferences between cotransferred promoters. ${ }^{169}$ New vector designs have already resulted from these studies but remain to be fully tested with primary hematopoietic cells. ${ }^{95}$ Vectors coexpressing two different coding sequences sepa- rated by an internal ribosomal entry site sequence ${ }^{170}$ or coding for artificially engineered bifunctional protein ${ }^{171,172}$ could also improve expression in hematopoietic cells and/or the sorting of transduced cells. Interesting prospects can be anticipated with the construction of lentivirus-derived vectors that are able to integrate into quiescent cells. ${ }^{97}$ In addition, the combination of different gene transfer tools has already been proven efficient, but still requires improvement. ${ }^{110}$ In vivo gene therapy will play a key role in gene therapy approaches in the near future, and the interest of using marker genes in animal models or preliminary marking clinical trials will be greatly emphasized in the development of this approach. In every aspect of gene transfer strategies, the use of a marker gene such as $n l s-L a c Z$ will provide very informative results that accurately estimate transduction efficiency, gene expression, and the overall quality of the technical process tested. Identification and full characterization of new efficient marker genes in the marking of hematopoietic cells remains a challenge, and several approaches, including green fluorescent protein activities, cell surface proteins, and markers with low immunogenic potential are fully investigated by many laboratories, including our own.

Beyond in vitro experiments and animal models, study of the fate and behavior of hematopoietic cells in humans will remain the ultimate and most relevant strategy for improving our understanding of normal hematopoiesis and the use of hematopoietic cells in gene therapy. We currently propose the use of the retroviral transfer of $n l s-L a c Z$ as a tool to follow the contribution of transduced autologous CD $34^{+}$peripheral blood progenitors in the reconstitution of lymphohematopoietic lineages in cancer patients undergoing treatment intensification. The short- and long-term expression of the transgene, immunogenicity of retrovirally transduced cells, and behavior and fate of autologous progenitors are important clues that will be addressed by this protocol precluding therapeutic gene therapy protocols.

\section{REFERENCES}

1. Mulligan RC. The basic science of gene therapy. Science. 1993;260:926-932.

2. Bronner-Fraser M, Fraser SE. Cell lineage analysis reveals multipotency of some avian neural crest cells. Nature. 1988;335:161-164.

3. Kimmel CB, Warga RM. Tissue-specific cell lineages originate in the gastrula of the zebrafish. Science. 1986; 231:365-368.

4. Weisblat DA, Sawyer RT, Stent GS. Cell lineage analysis by intracellular injection of a tracer enzyme. Science. 1978;202:1295-1298.

5. Weisblat DA, Zackson SL, Blair SS, Young JD. Cell lineage analysis by intracellular injection of fluorescent tracers. Science. 1980;209:1538-1541.

6. LeDouarin NM. Particularités du noyau interphasique chez la caille japonaise (Coturnix coturnix japonica): utilisation de ses particularités comme "marquage biologique" dans des recherches. Bull Biol Fr Belg. 1969; 103:435-452. 
7. Sanes JR, Rubenstein JRL, Nicolas J-F. Use of a recombinant retrovirus to study post-implantation cell lineage in mouse embryos. EMBO J. 1986;5:3133-3142.

8. Varmus H. Retroviruses. Science. 1988;240:1427-1435.

9. Brenner MK, Rill DR, Holladay MS, et al. Gene marking to determine whether autologous marrow infusion restores long-term haemopoiesis in cancer patients. Lancet. 1993;342:1134-1137.

10. Dunbar CE, Cottler-Fox M, O’Shaughnessy JA, et al. Retrovirally marked CD34-enriched peripheral blood and bone marrow cells contribute to long-term engraftment after autologous transplantation. Blood. 1995;85: 3048-3057.

11. Desseiroth $\mathrm{AD}, \mathrm{Zu} \mathrm{Z}$, Claxton D, et al. Genetic marking shows that $\mathrm{Ph}^{+}$cells present in autologous transplants of chronic myelogenous leukemia (CML) contribute to relapse after autologous bone marrow in CML. Blood. 1994;83:3068-3076.

12. Hanania EG, Giles RE, Kavanagh J, et al. Results of MDR-1 vector modification trial indicate that granulocyte/macrophage colony-forming unit cells do not contribute to posttransplant hematopoietic recovery following intensive systemic therapy. Proc Natl Acad Sci USA. 1996;93:15346-15351.

13. Lu L, Xiao M, Wade Clapp D, Li ZH, Broxmeyer HE. High efficiency retroviral-mediated gene transduction into single isolated immature and replatable $\mathrm{CD} 34^{3+}$ hematopoietic stem/progenitor cells from human umbilical cord blood. J Exp Med. 1993;178:2089-2096.

14. Valera A, Perales JC, Hatzoglou M, Bosch F. Expression of the neomycin-resistance (neo) gene induces alterations in gene expression and metabolism. Hum Gene Ther. 1994;5:449-456.

15. Artelt P, Grannemann R, Stocking C, Friel J, Bartsch J, Hauser H. The prokaryotic neomycin-resistance-encoding gene acts as a transcriptional silencer in eukaryotic cells. Gene. 1991;99:249-254.

16. Fernex C, Dubreuil P, Mannoni P, Bagnis C. Cre/loxPmediated excision of a neomycin resistance expression unit from an integrated retroviral vector increases the LTR-driven transcription in human hematopoietic cells. J Virol. 1997;71:7533-7540.

17. Kalmins A, Otto K, Ruther U, Muller-Hill B. Sequence of the LacZ gene of E. coli. EMBO J. 1983;2:593-597.

18. Lederberg J. The $\beta$-galactosidase of Escherichia coli, strain K-12. Genetics. 1950;35:381-391.

19. Weiss DJ, Liggitt D, Clark JG. In situ histochemical detection of $\beta$-galactosidase activity in lung: assessment of $\mathrm{X}-\mathrm{Gal}$ reagent in distinguishing lacZ gene expression and endogenous $\beta$-galactosidase activity. Hum Gene Ther. 1997;8:1545-1554.

20. Lojda Z. Indigogenic methods for glycosidases: an improved method for $\beta$-galactosidase and its application to localization studies of the enzymes in the intestine and in other tissues. Histochemie. 1970;23:266-288.

21. Murnane RD, Wright RW, Hoffman KR, Prieur DJ. Expression of $\beta$-galactosidase in preimplantation bovine and porcine embryos. Proc Soc Exp Biol Med. 1990;194: 144-148.

22. Kalderon D, Roberts BL, Richardson WD, Smith AE. A short amino acid sequence able to specify nuclear location. Cell. 1984;39:499-509.

23. Huang C, Samsonoff WA, Grzelecki A. Vaccinia virus recombinants expressing an 11 -kilodalton $\beta$-galactosidase fusion protein incorporate active $\beta$-galactosidase in virus particles. J Virol. 1988;62:3855-3861.
24. Turner DL, Cepko CL. A common progenitor for neurons and glia persists in rat retina late in development. Nature. 1987;328:131-136.

25. Bonnerot C, Rocancourt D, Briand P, Grimber G, Nicolas J-FA. $\beta$-galactosidase hybrid protein targeted to nuclei as a marker for developmental studies. Proc Natl Acad Sci USA. 1987;84:6795-6799.

26. Galileo DS, Gray GE, Owens GC, Majors J, Sanes JR. Neurons and glia arise from a common progenitor in chicken optic tectum: demonstration with two retroviruses and cell type-specific antibodies. Proc Natl Acad Sci USA. 1990;87:458-462.

27. Miller JH. Assay of $\beta$-galactosidase. In: Miller JH, ed. Experiments in Molecular Genetics. Cold Spring Harbor, NY: Cold Spring Harbor Press; 1972:p352-355.

28. MacGregor GR, Mogg AE, Burke JF, Caskey CT. Histochemical staining of clonal mammalian cell lines expressing $E$. coli $\beta$-galactosidase indicates heterogeneous expression of the bacterial gene. Somat Cell Mol Genet. 1987;13:253-265.

29. Couffinhal T, Kearney M, Sullivan A, Silver M, Tsurumi Y, Isner JM. Histochemical staining following lacZ gene transfer underestimates transfection efficiency. Hum Gene Ther. 1997;8:929-934.

30. Fiering SN, Roederer M, Nolan GP, Micklem DR, Parks DR, Herzenberg LA. Improved FACS-Gal flow cytometric analysis and sorting of viable eukaryotic cells expressing reporter gene constructs. Cytometry. 1991;12:291-301.

31. Nolan GP, Fiering S, Nicolas JF, Herzenberg LA. Fluorescence-activated cell analysis and sorting of viable mammalian cells based on $\beta$-D-galactosidase activity after transduction of E. coli LacZ. Proc Natl Acad Sci USA. 1988;85:2603-2607.

32. Strair RK, Towle M, Smith BR. Retroviral-mediated gene transfer into bone marrow progenitor cells: use of $\beta$-galactosidase as a selectable marker. Nucleic Acids Res. 1990;18:4759-4762.

33. Zhang YZ, Naleway JJ, Larison KD, Huang Z, Haugland RP. Detecting $L a c Z$ gene expression in living cells with new lipophilic, fluorogenic $\beta$-galactosidase substrates. FASEB J. 1991;5:3108-3113.

34. Brody SL, Metzger M, Danel C, Rosenfeld MA, Crystal RG. Acute responses of non-human primates to airway delivery of an adenovirus vector containing the human cystic fibrosis transmembrane conductance regulator cDNA. Hum Gene Ther. 1994;5:821-836.

35. Simon RH, Engelhardt JF, Yang Y, et al. Adenovirusmediated transfer of the CFTR gene to lung of nonhuman primates: toxicity study. Hum Gene Ther. 1993;4: 771-780.

36. Yei S, Mittereder N, Wert S, Whittsett JA, Willmott RW, Trapnell BC. In vivo evaluation of the safety of adenovirus-mediated transfer of the human cystic fibrosis transmembrane conductance regulator cDNA to the lung. Hum Gene Ther. 1994;5:731-744.

37. Davidson BL, Doran SE, Shewach DS, Latta JM, Hartman JW, Roessler BJ. Expression of Escherichia coli $\beta$-galactosidase and rat HPRT in the CNS of Macaca mulatta following adenoviral-mediated gene transfer. Exp Neurol. 1994;125:258-267.

38. Lisosovski F, Cadusseau J, Akli S, et al. In vivo transfer of a marker gene to study motoneural development. Neuroreport. 1994;5:1069-1072.

39. Ridoux V, Robert JJ, Zhang X, Perricaudet M, Mallet J, Le Gal La Salle G. The use of adenovirus vectors for 
intracerebral grafting of transfected nervous cells. Neuroreport. 1994;5:801-804.

40. Roessler BJ, Davidson BL. Direct plasmid-mediated transfection of adult murine brain cells in vivo using cationic liposomes. Neurosci Lett. 1994;167:5-10.

41. Bennett J, Wilson J, Sun D, Forbes B, Maguire A. Adenovirus vector-mediated in vivo gene transfer into adult murine retina. Invest Ophthalmol Vis Sci. 1994;35: 2535-2542.

42. Jomary C, Piper TA, Dickson G, et al. Adenovirusmediated gene transfer to murine retinal cells in vitro and in vivo. FEBS Lett. 1994;347:117-122.

43. Li F, Linton GF, Sekhsaria S, et al. CD34 ${ }^{+}$peripheral blood progenitors as a target for genetic correction of the two flavocytochrome b558 defective forms of chronic granulomatous disease. Blood. 1994;84:53-58.

44. Jensen UB, Jensen TG, Jensen PK, et al. Gene transfer into cultured human epidermis and its transplantation onto immunodeficient mice: an experimental model for somatic gene therapy. J Invest Dermatol. 1994;103:391394.

45. Setoguchi Y, Jaffe HA, Danel C, Crystal RG. Ex vivo and in vivo gene transfer to the skin using replication-deficient recombinant adenovirus vectors. J Invest Dermatol. 1994;103:415-412.

46. Morris BD, Drazan KE, Csete ME, et al. Adenoviralmediated gene transfer to bladder in vivo. J Urol. 1994; 152:506-509.

47. Maeda H, Danel C, Crystal RG. Adenovirus-mediated transfer of human lipase complementary DNA to the gallbladder. Gastroenterology. 1994;106:1638-1644.

48. Kitamura M, Taylor S, Unwin R, Burton S, Shimizu F, Fine LG. Gene transfer into the rat glomerulus via a mesangial cell vector: site-specific delivery, in situ amplification, and sustained expression of an exogenous gene in vivo. J Clin Invest. 1994;94:497-505.

49. Moullier P, Friedlander G, Calise D, Ronco P, Perricaudet M, Ferry N. Adenoviral-mediated gene transfer to renal tubular cells in vivo. Kidney Int. 1994;45:1220-1225.

50. Conte MS, Birinyi LK, Miyata T, et al. Efficient repopulation of denuded rabbit arteries with autologous genetically modified endothelial cells. Circulation. 1994;89: 2161-2169.

51. French BA, Mazur W, Geske RS, Bolli R. Direct in vivo gene transfer into porcine myocardium using replicationdeficient adenoviral vectors. Circulation. 1994;90:24142424.

52. Lal B, Indurti RR, Couraud PO, Goldstein GW, Laterra J. Endothelial cell implantation and survival within experimental gliomas. Proc Natl Acad Sci USA. 1994;91: 9695-9699.

53. Lemarchand P, Jones M, Danel C, Yamada I, Mastrangeli A, Crystal RG. In vivo adenovirus-mediated gene transfer to lungs via pulmonary arteries. J Appl Physiol. 1994;76:2840-2845.

54. Steg PG, Feldman LJ, Scoazec JY, et al. Arterial gene transfer to rabbit endothelial and smooth muscle cells using percutaneous delivery of an adenoviral vector. Circulation. 1994;90:1648-1656.

55. Acsadi G, Jani A, Massie B, et al. A differential efficiency of adenovirus-mediated in vivo gene transfer into skeletal muscles of different maturity. Hum Mol Genet. 1994;3: $579-584$.

56. Alameddine HS, Quantin B, Cartaud A, Dehaupas M, Mandel JL, Fardeau M. Expression of a recombinant dystrophin in mdx mice using adenovirus vector. Neuromuscul Disord. 1994;4:193-203.

57. French BA, Mazur W, Ali NM, et al. Percutaneous transluminal in vivo gene transfer by recombinant adenovirus in normal porcine coronary arteries, and two models of coronary restenosis. Circulation. 1994;90:2402-2413.

58. Rando TA, Blau HM. Primary mouse myoblast purification, characterization, and transplantation for cell-mediated gene therapy. J Cell Biol. 1994;125:1275-1287.

59. Vitadello M, Schiaffino MV, Picard A, Scarpa M, Schiaffino S. Gene transfer in regenerating muscles. Hum Gene Ther. 1994;5:11-18.

60. Bralet MP, Branchereau S, Brechot C, Ferry N. Cell lineage study in the liver using retroviral-mediated gene transfer: evidence against the streaming of hepatocytes in normal liver. Am J Pathol. 1994;144:849-854.

61. Csete ME, Drazan KE, van Bree M, et al. Adenovirusmediated gene transfer in the transplant setting: conditions for expression of transferred genes in cold-preserved hepatocytes. Transplantation. 1994;57:1502-1507.

62. Drazan KE, Shen XD, Csete ME, et al. In vivo adenoviral-mediated human p53 tumor suppressor gene transfer and expression in rat liver after resection. Surgery. 1994; 116:197-203.

63. Shaked A, Csete ME, Drazan KE, Bullington D, Wu L, Busuttil RW. Adenovirus-mediated gene transfer in the transplant setting: successful expression of transferred cDNA in syngeneic liver grafts. Transplantation. 1994;57: $1508-1511$.

64. Mastrangeli A, O'Connell B, Aladib W, Fox PC, Baum BJ, Crystal RG. Direct in vivo adenovirus-mediated gene transfer to salivary glands. Am J Physiol. 1994;266: G1146-G1155.

65. Sikes ML, O’Malley BW, Finegold MJ, Ledley FD. In vivo gene transfer into rabbit thyroid follicular cells by direct DNA injection. Hum Gene Ther. 1994;5:837-844.

66. Yang Y, Nunes FA, Berencsi K, Furth EE, Gonczol E, Wilson JM. Cellular immunity to viral antigens limits E1-deleted adenoviruses for gene therapy. Proc Natl Acad Sci USA. 1994;91:4407-4411.

67. Savatier P, Morgenstern J, Beddington RSP. Permissiveness to murine leukemia virus expression during preimplantation and early postimplantation mouse development. Development. 1990;109:655-665.

68. Volckaert FA, Hellemans BA, Galbusera P, Ollevier F, Sekkali B, Belayew A. Replication, expression, and fate of foreign DNA during embryonic and larval development of the African catfish (Clarias gariepinus). Mol Mar Biol Biotechnol. 1994;3:57-69.

69. Goodman S, Xiao X, Donahue RE, et al. Recombinant adeno-associated virus-mediated gene transfer into hematopoietic progenitor cells. Blood. 1994;84:1492-1500.

70. Zhou SZ, Cooper S, Kang LY, et al. Adeno-associated virus 2-mediated high efficiency gene transfer into immature and mature subsets of hematopoietic progenitor cells in human umbilical cord blood. J Exp Med. 1994;179: 1867-1875.

71. Bagnis C, Gravis G, Imbert AM, et al. Retroviral transfer of the nlsLacZ gene into human $\mathrm{CD} 34^{+}$cell populations and into TF-1 cells: future prospects in gene therapy. Hum Gene Ther. 1994;5:1325-1333.

72. Riddell SR, Elliott M, Lewinsohn DA, et al. T-cell mediated rejection of gene-modified HIV-specific cytotoxic T lymphocytes in HIV-infected patients. Nat Med. 1996;2:216-223.

73. Bonini C, Ferrari G, Verzeletti S, et al. HSV-TK gene 
transfer into donor lymphocytes for control of allogeneic graft versus leukemia. Science. 1997;276:1719-1724.

74. Abina MA, Lee MG, Descamps V, et al. LacZ gene transfer into tumor cells abrogates tumorigenicity and protects mice against the development of further tumors. Gene Ther. 1996;3:212-216.

75. Stockschlader MAR, Schuenning FG, Graham TC, Storb $\mathrm{R}$. Transplantation of retrovirus-transduced canine keratinocytes expressing the $\beta$-galactosidase. Gene Ther. 1994; $1: 317-322$.

76. Kessler PD, Podsakoff GM, Chen X, et al. Gene delivery to skeletal muscle results in sustained expression and systemic delivery of a therapeutic protein. Proc Natl Acad Sci USA. 1996;93:14082-14087.

77. Schreiber JH, Schisa JA, Wilson JM. Recombinant retroviruses containing novel reporter genes. Biotechniques. 1993;14:818-822.

78. Zolotukhin S, Potter M, Hauswirth WW, Guy J, Muzyczka NA. "Humanized" green fluorescent protein cDNA adapted for high-level expression in mammalian cells. J Virol. 1996;70:4646-4654.

79. Anderson MT, Tjioe IM, Lorincz MC, et al. Simultaneous fluorescence-activated cell sorter analysis of two distinct transcriptional elements within a single cell using engineered green fluorescent proteins. Proc Natl Acad Sci USA. 1996;93:8508-8511.

80. Crameri A, Whitehorn EA, Tate E, Stemmer WPC. Improved green fluorescent protein by molecular evolution using DNA shuffling. Nat Biotechnol. 1996;14:315319.

81. Persons DA, Allay JA, Allay ER, et al. Retroviralmediated transfer of the green fluorescent protein gene into murine hematopoietic cells facilitates scoring and selection of transduced progenitors in vitro and identification of genetically modified cells in vivo. Blood. 1997; 90:1777-1786.

82. Cheng L, Du C, Murray D, et al. A GFP reporter system to assess gene transfer and expression in human hematopoietic progenitor cells. Gene Ther. 1997;4:1013-1022.

83. Jolly D. Viral vector systems for gene therapy. Cancer Gene Ther. 1994;1:51-64.

84. Neering SJ, Hardy SF, Minamoto D, Spratt SK, Jordan CJ. Transduction of primitive human hematopoietic cells with recombinant adenovirus vectors. Blood. 1996;88: 1147-1155.

85. Miller DG, Edwards RH, Miller AD. Cloning of the cellular receptor for amphotropic murine retroviruses reveals homology to that for gibbon ape leukemia virus. Proc Natl Acad Sci USA. 1994;91:78-82.

86. Van Zeijl M, Johann SV, Cloos E, et al. A human amphotropic retrovirus receptor is a second member of the gibbon ape leukemia virus receptor family. Proc Natl Acad Sci USA. 1994;91:1168-1172.

87. Mikawa T, Fischman DA, Dougherty JP, Brown AMC. In vivo analysis of a new $L a c Z$ retrovirus vector suitable for cell lineage marking in avian and other species. Exp Cell Res. 1991;195:516-523.

88. Price J, Turner D, Cepko C. Lineage analysis in the vertebrate nervous system by retrovirus-mediated gene transfer. Proc Natl Acad Sci USA. 1987;84:156-160.

89. Faustinella F, Kwon H, Serrano F, Belmont JW, Caskey CT, Aguilar-Cordova E. A new family of murine retroviral vectors with extended multiple cloning sites for gene insertion. Hum Gene Ther. 1994;5:307-312.

90. Hawley RG, Lieu FHL, Fong AZC, Hawley TS. Versatile vectors for potential use in gene therapy. Gene Ther. 1994;1:136-138.

91. Saleh M. A retroviral vector that allows efficient coexpression of two genes and the versatility of alternate selection markers. Hum Gene Ther. 1997;8:879-893.

92. Wiznerowicz M, Fong AZC, Mackiewicz A, Hawley RG. Double-copy bicistronic retroviral vector platform for gene therapy and tissue engineering: application to melanoma vaccine development. Gene Ther. 1997;4:10611068.

93. Miller AD, Buttimore C. Redesign of retrovirus packaging cell lines to avoid recombination leading to helper virus production. Mol Cell Biol. 1986;6:2895-2902.

94. Danos O, Mulligan RC. Safe and efficient generation of recombinant retroviruses with amphotropic and ecotropic host ranges. Proc Natl Acad Sci USA. 1988;85:6460-6464.

95. Baum C, Hegewisch-Becker S, Eckert HG, Stocking C, Ostertag W. Novel retroviral vectors for efficient expression of the multidrug resistance (mdr-1) gene in early hematopoietic cells. J Virol. 1995;69:7541-7547.

96. Miller DG, Adam MA, Miller AD. Gene transfer by retrovirus vectors occurs only in cells that are actively replicating at the time of infection. Mol Cell Biol. 1990; 10:4239-4245.

97. Naldini L, Blomer U, Gallay P, et al. In vivo gene delivery and stable transduction of nondividing cells by a lentiviral vector. Science. 1996;272:263-267.

98. Markowitz D, Goff S, Bank A. Construction and use of a safe and efficient packaging cell line. Virology. 1988;167: 400-406.

99. Miller AD, Garcia JV, von Suhr N, Lynch CM, Wilson C, Eiden MV. Construction and properties of retrovirus packaging cells based on gibbon ape leukemia virus. J Virol. 1991;65:2220-2224.

100. Pear WS, Nolan GP, Scott ML, Baltimore D. Production of high-titer helper-free retroviruses by transient transfection. Proc Natl Acad Sci USA. 1993;90:8392-8396.

101. Cosset FL, Takeuchi Y, Battini JL, Weiss RA, Collins MKL. High-titer packaging cells producing recombinant retroviruses resistant to human serum. $J$ Virol. 1995;69: $7430-7436$.

102. Van Beusechem VW, Bakx TA, Kaptein LCM, et al. Retrovirus-mediated gene transfer into rhesus monkey hematopoietic stem cells: the effect of viral titers on transduction efficiency. Hum Gene Ther. 1993;4:239-247.

103. Van Beusechem VW, Bart-Baumeister JAK, Bakx TA, Kaptein LCM, Levinski RJ, Valerio D. Gene transfer into nonhuman primate $\mathrm{CD} 34^{+} \mathrm{CD} 11 \mathrm{~b}^{-}$bone marrow progenitor cells capable of repopulating lymphoid and myeloid lineages. Hum Gene Ther. 1994;5:295-305.

104. Paul RW, Morris D, Hess BW, Dunn J, Overell RW. Increased viral titer through concentration of viral harvests from retroviral packaging lines. Hum Gene Ther. 1993;4:609-615.

105. Xu LC, Young HA, Blanco M, Kessler S, Roberts AB, Karlsson S. Poor transduction efficiency of human hematopoietic progenitor cells by a high titer amphotropic retrovirus producer cell clone. J Virol. 1994;68:76347636.

106. Forestell SP, Bohnlein E, Rigg RJ. Retroviral end-point titer is not predictive of gene transfer efficiency: implications for vector production. Gene Ther. 1995;2:723-730.

107. Bagnis C, Chischportich C, Imbert AM, Van Den Broeke A, Cornet V, Mannoni P. Efficiency of retroviral transduction into hematopoietic cells by cocultivation does not correlate with viral titer. Cancer Gene Ther. 1997;4:5-8. 
108. Cosset FL, Russel SJ. Targeting retrovirus entry. Gene Ther. 1996;3:946-956.

109. Kotin RM. Prospects for the use of adeno-associated virus as a vector for human gene therapy. Hum Gene Ther. 1994;5:793-801.

110. Malik P, McQuiston SA, Yu X-J, et al. Recombinant adeno-associated virus mediates a high level of gene transfer but less efficient integration in the K562 human hematopoietic cell line. J Virol. 1997;71:1776-1783.

111. Shelling AN, Smith MG. Targeted integration of transfected and infected adeno-associated virus vectors containing the neomycin resistance gene. Gene Ther. 1994;1: 165-169.

112. Podsakoff G, Wong KK, Chatterjee S. Efficient gene transfer into nondividing cells by adeno-associated virusbased vectors. J Virol. 1994;68:5656-5666.

113. Feng M, Jackson WH, Goldman CK, et al. Stable in vivo gene transduction via a novel adenoviral/retroviral chimeric vector. Nat Biotechnol. 1997;15:866-870.

114. Bagnis C, Mannoni P. Stem cell-based gene therapy. Oncologist. 1997;2:196-202.

115. Kitamura T, Tange T, Terasawa T, et al. Establishment and characterization of a unique human cell line that proliferates dependently on GM-CSF, IL-3, or erythropoietin. J Cell Physiol. 1989;140:323-334.

116. Hatzfeld A, Batard P, Panterne B, Taieb F, Hatzfeld J. Increased stable retroviral gene transfer in early hematopoietic progenitors released from quiescence. Hum Gene Ther. 1996;7:207-213.

117. Humeau L, Chabannon C, Firpo MT, Bagnis C, Roncarolo M-G, Namikawa R. Successful reconstitution of human hematopoiesis in the SCID-hu mouse by genetically modified, highly enriched progenitors isolated from fetal liver. Blood. 1997;90:3496-3506.

118. Imbert AM, Bagnis C, Galindo R, Chabannon C, Mannoni P. A neutralizing anti-TGF- $\beta 1$ antibody promotes proliferation of $\mathrm{CD} 34^{+}$Thy $-1^{+}$peripheral blood progenitors and increases the number of transduced progenitors. Exp Hematol. 1998;26:374-381.

119. Maciejewski JP, Bruening EE, Donahue RE, Mocarski ES, Young NS, St Jeor SC. Infection of hematopoietic progenitor cells by human cytomegalovirus. Blood. 1992; 80:170-178.

120. Hege KM, Roberts MR. T-cell gene therapy. Curr Opin Biotech. 1996;7:629-634.

121. Galy A, Verma S, Barcena A, Spits H. Precursors of $\mathrm{CD} 3{ }^{+} \mathrm{CD} 4{ }^{+} \mathrm{CD}^{+}$cells in the human thymus are defined by expression of CD34: delineation of early events in human thymic development. J Exp Med. 1993;178: 391-401.

122. Culver KW, Ram Z, Wallbridge S, Ishii H, Oldfield EH, Blaese RM. In vivo gene transfer with retroviral vectorproduced cells for treatment of experimental brain tumors. Science. 1992;256:1550-1552.

123. Tiberghien P, Reynolds CW, Keller J, et al. Ganciclovir treatment of herpes simplex thymidine kinase-transduced primary $\mathrm{T}$ lymphocytes: an approach for specific in vivo donor T-cell depletion after bone marrow transplantation. Blood. 1994;84:1333-1341.

124. Mavilio F, Ferrari G, Rossini S, et al. Peripheral blood lymphocytes as target cells of retroviral vector-mediated gene transfer. Blood. 1994;83:1988-1997.

125. Finer MH, Dull DJ, Qin L, Farson D, Roberts MR. Kat: a high-efficiency retroviral transduction system for human T lymphocytes. Blood. 1994;83:43-50.

126. Imbert AM, Costello R, Imbert J, Mannoni P, Bagnis C.
Highly efficient retroviral gene transfer into human primary $\mathrm{T}$ lymphocytes derived from the peripheral blood. Cancer Gene Ther. 1994;1:259-265.

127. Rosenberg SA, Aebersold P, Cornetta K, et al. Gene transfer into humans: immunotherapy of patients with advanced melanoma using tumor-infiltrating lymphocytes modified by retroviral gene transduction. $N$ Engl J Med. 1990;323:570-578.

128. Culver K, Cornetta K, Morgan R, et al. Lymphocytes as cellular vehicles for gene therapy in mouse and man. Proc Natl Acad Sci USA. 1991;88:3155-3159.

129. Di Ianni M, Casciari C, Ciurnelli $\mathrm{R}$, et al. $\beta$-galactosidase-transduced $\mathrm{T}$ lymphocytes: a comparison between stimulation by either PHA and IL-2 or a mixed lymphocyte reaction. Haematologica. 1996;81:410-417.

130. Sutkowski N, Kuo ML, Amenta PS, Dougherty JP, Ron Y. A peripheral blood-derived monolayer supports longterm cultures of human $\mathrm{CD}^{+}{ }^{+}$and $\mathrm{CD}^{+} \mathrm{T}$ lymphocytes. Blood. 1995;85:3213-3222.

131. Gu J, Kuo ML, Rivera A, Sutkowski N, Ron Y, Dougherty JP. A murine model for genetic manipulation of the T cell compartment. Exp Hematol. 1996;24:1432-1440.

132. Morecki S, Karson E, Cornetta K, et al. Retrovirusmediated gene transfer into $\mathrm{CD}^{+}{ }^{+}$and $\mathrm{CD} 8^{+}$human $\mathrm{T}$ cells subsets derived from tumor-infiltrating lymphocytes and peripheral blood mononuclear cells. Cancer Immunol Immunother. 1991;32:342-348.

133. Staal FJ, Res PC, Weijer K, Spits H. Development of retrovirally marked human $\mathrm{T}$ progenitor cells into mature thymocytes. Int Immunol. 1995;7:1301-1309.

134. Aicher A, Westermann J, Cayeux S, et al. Successful retroviral-mediated transduction of a reporter gene in human dendritic cells: feasibility of therapy with genemodified antigen-presenting cells. Exp Hematol. 1997;25: 39-44.

135. Henderson RA, Nimgaonkar MT, Watkins SC, Robbins PD, Ball ED, Finn OJ. Human dendritic cells engineered to express high levels of the human epithelial tumor antigen (MUC-1). Cancer Res. 1996;56:3763-3770.

136. Reeves ME, Royal RE, Lam JS, Rosenberg SA, Hwu P. Retroviral transduction of human dendritic cells with a tumor-associated antigen gene. Cancer Res. 1996;56: 5672-5677.

137. Weir JP, Meltzer MS. Transfection of human immunodeficiency virus type 1 proviral DNA into primary human monocytes. Cell Immunol. 1993;148:157-165.

138. Snodgrass R, Keller G. Clonal fluctuation within the hematopoietic system of mice reconstituted with retrovirus-infected stem cells. EMBO J. 1987;6:3955-3960.

139. Jordan CT, Lemischka IR. Clonal and systemic analysis of long-term hematopoiesis in the mouse. Genes Dev. 1990;4:220-232.

140. Van Zant G, Chen JJ, Scott-Micus K. Developmental potential of hematopoietic stem cells determined using retrovirally marked allophenic marrow. Blood. 1991;77: 756-763.

141. Dick JE, Mgli MC, Huszar D, Phillips RA, Bernstein A. Introduction of a selectable gene into primitive stem cells capable of long-term reconstitution of the hemopoietic system of W/Wv mive. Cell. 1985;42:71-79.

142. Lemischka IR, Raulet DH, Mulligan RC. Developmental potential and dynamic behavior of hematopoietic stem cells. Cell. 1986;45:917-927.

143. Larochelle A, Vormoor J, Hanenberg H, et al. Identification of primitive human hematopoietic cells capable of 
repopulating NOD/SCID mouse bone marrow: implications for gene therapy. Nat Med. 1996;2:1329-1337.

144. Kiem HP, Darovsky B, von Kalle C, et al. Retrovirusmediated gene transduction into canine peripheral blood repopulating cells. Blood. 1994;83:1467-1473.

145. Kwok WW, Schuening F, Stead RB, Miller AD. Retroviral transfer of genes into canine hemopoietic progenitor cells in culture: a model for human gene therapy. Proc Natl Acad Sci USA. 1986;83:4552-4555.

146. Carter RF, Abrams-Ogg ACG, Dick JE, et al. Autologous transplantation of canine long-term marrow culture cells genetically marked by retroviral vectors. Blood. 1992;79:356-364.

147. Culver KW, Morgan RA, Osborne WRA, et al. In vivo expression and survival of gene-modified T lymphocytes in rhesus monkeys. Hum Gene Ther. 1990;1:399-410.

148. Kantoff PW, Gillio AP, MacLachlin JR, et al. Expression of human adenosine deaminase in nonhuman primates after retrovirus-mediated gene transfer. J Exp Med. 1987; 166:219-234.

149. Champseix C, Maréchal V, Khazaal I, et al. A cell surface marker gene transferred with a retroviral vector into $\mathrm{CD}^{+}{ }^{+}$cord blood cells is expressed by their T-cell progeny in the SCID-hu thymus. Blood. 1996;88:107-113.

150. Bagnis C, Cosset FL, Samarut J, Moscovici G, Moscovici C. Leukemogenicity of v-myb transformed monoblast cells can be modulated by normal bone marrow environment. Oncogene. 1993;8:737-743.

151. Solari F, Flamant F, Cherel Y, Wyers M, Jurdic P. The osteoclast generation: an in vitro and in vivo study with a genetically labelled avian monocytic cell line. J Cell Sci. 1996;109:1203-1213.

152. Brenner MK, Rill RD, Moen RC, et al. Gene-marking to trace origin of relapse after autologous bone-marrow transplantation. Lancet. 1993;341:85-86.

153. Nolta JA, Crooks GM, Overell RW, Williams DE, Kohn DB. Retroviral vector-mediated gene transfer into primitive human hematopoietic progenitor cells: effects of mast cell growth factor (MGF) combined with other cytokines. Exp Hematol. 1992;20:1065-1071.

154. Bodine DM, Karlsson S, Nienhuis AW. Combinations of interleukins 3 and 6 preserves stem cell function in culture and enhances retrovirus-mediated gene transfer into hematopoietic stem cells. Proc Natl Acad Sci USA. 1989;86:8897-8900.

155. Moore KA, Desseiroth AB, Reading CL, Williams DE, Belmont JW. Stromal support enhances cell-free retroviral vector transduction of human bone marrow long-term culture-initiating cells. Blood. 1992;79:1393-1399.

156. Dube ID, Kruth S, Abrams-Ogg A, et al. Preclinical assessment of human hematopoietic progenitor cell transduction in long-term marrow cultures. Hum Gene Ther. 1996;7:2089-2100.

157. Moritz T, Patel VP, Williams DA. Bone marrow extracellular matrix molecules improve gene transfer into human hematopoietic cells via retroviral vectors. J Clin Invest. 1994;93:1451-1457.

158. Moritz T, Dutt P, Xiao X, et al. Fibronectin improves transduction of reconstituting hematopoietic stem cells by retroviral vectors: evidence of direct viral binding to chymotryptic carboxy-terminal fragments. Blood. 1996; 88:855-862.

159. Couture LA, Mullen CA, Morgan RA. Retroviral vectors containing chimeric promoter/enhancer elements exhibit cell-type-specific gene expression. Hum Gene Ther. 1994; 5:667-677.

160. Bauer TR, Osborne WRA, Kwok WW, Hickstein DD. Expression from leukocyte integrin promoters in retroviral vectors. Hum Gene Ther. 1994;5:709-716.

161. Vile R, Miller N, Chernajovsky Y, Ian H. A comparison of the properties of different retroviral vectors containing the murine tyrosinase promoter to achieve transcriptionally targeted expression of the HSVtk or IL-2 genes. Gene Ther. 1994;1:307-316.

162. Johnson MI, Forth DF. Present status and future prospects for HIV therapies. Science. 1993;260:1286-1293.

163. Yu M, Poeschla E, Wong Staal F. Progress towards gene therapy for HIV infection. Gene Ther. 1994;1:13-26.

164. Hoeben RC, Migchielsen AA, van der Jagt RC, van Ormondt $\mathrm{H}$, van der $\mathrm{Eb} \mathrm{AJ}$. Inactivation of Moloney murine leukemia virus long terminal repeat in murine fibroblast cell lines is associated with methylation and dependent on its chromosomal position. J Virol. 1991;65: 904-912.

165. Duch M, Paludan K, Jorgensen P, Pedersen FS. Lack of correlation between basal expression levels and susceptibility to transcriptional shutdown among single-gene murine leukemia virus vector proviruses. J Virol. 1994;68: 5569-5601.

166. MacLachlin JR, Mittereder N, Daucher MB, Kadan M, Eglitis MA. Factors affecting retroviral vector function and structural integrity. Virology. 1993;195:1-5.

167. Nilsson E, Lendhal U. Transient expression of a human $\beta$-actin promoter $/ L a c Z$ gene introduced into mouse embryos correlates with a low degree of methylation. Mol Reprod Dev. 1993;34:149-157.

168. Challita PM, Kohn DB. Lack of expression from a retroviral vector after transduction of murine hematopoietic stem cells is associated with methylation in vivo. Proc Natl Acad Sci USA. 1994;91:2567-2571.

169. Emerman M, Temin HM. Comparison of promoter suppression in avian and murine retrovirus vectors. Nucleic Acids Res. 1986;14:9381-9396.

170. Ghattas IR, Sanes JR, Majors JE. The encephalomyocarditis virus internal ribosome entry site allows efficient coexpression of two genes from a recombinant provirus in cultured cells and embryo. Mol Cell Biol. 1991;11:58485859.

171. Friedrich G, Soriano P. Promoter traps in embryonic stem cells: a genetic screen to identify and mutate developmental genes in mice. Gene Dev. 1991;5:1513-1523.

172. Baron M, Reynes JP, Stassi D, Tiraby G. A selectable bifunctional $\beta$-galactosidase: phleomycin resistance fusion protein as a potential marker for eukaryotic cells. Gene. 1992;114:239-243. 